(C) The European Political Science Association, 2017. This is an Open Access article, distributed under the terms of the Creative Commons Attribution licence (http://creativecommons.org/licenses/by/4.0/), which permits unrestricted re-use, distribution, and reproduction in any medium, provided the original work is properly cited.

doi:10.1017/psrm.2017.35

\title{
Competing With the Dragon: Employment Effects of Chinese Trade Competition in 17 Sectors Across 18 OECD Countries*
}

\author{
STEFAN THEWISSEN AND OLAF VAN VLIET
}

\begin{abstract}
$C$ hina's rapid rise on the global economic stage has substantial and unequal employment effects in advanced industrialized democracies given China's large volume of low-wage labor. Thus far, these effects have not been analyzed in the comparative political economy literature. Building on pooled time-series data, we analyze the effects of Chinese trade competition across 17 sectors in 18 countries. We devote attention to a new channel, increased competition from China in foreign export markets. Our empirical findings reveal overall employment declines in sectors more exposed to Chinese imports. Furthermore, our results suggest that employment effects are not equally shared across skill levels, as the share of hours worked worsens for low-skilled workers.
\end{abstract}

$\mathrm{D}$ uring the past two decades China's manufacturing exports to advanced industrialized democracies have grown enormously. As a result of its liberalization of product and financial markets, its growth in productivity, and its World Trade Organisation accession in 2001, China became the world's largest exporter of goods in the span of two decades between early 1990s and 2010 (OECD 2012). Given China's enormous volume of low-wage labor, illustrated by the massive rural-urban migration, its rapid exports growth can be considered as an export shock that can have substantial consequences for employees in OECD countries.

Globalization as such has a long history of being examined as a cause of rising inequality of labor market outcomes in the comparative political economy literature. An important branch of this literature has been focused on the association between economic globalization and earnings inequality. As a measure of economic globalization, studies tend to use imports and exports with less developed countries summed together as a percentage of gross domestic product (GDP) as indicator. Most studies report insignificant associations between this measure and various measures of earnings inequality (Rueda and Pontusson 2000; Pontusson et al. 2002; Oliver 2008).

\footnotetext{
* Stefan Thewissen is a Postdoctoral Research Officer at the Department of Social Policy and Intervention, Institute for New Economic Thinking, and Nuffield College, University of Oxford, Walton Well Road, Oxford OX2 6ED; and a guest staff member at the Department of Economics, Leiden University (stefan.thewissen@spi. ox.ac.uk) (orcid.org/0000-0003-3907-1976). Olaf van Vliet is an Associate Professor at the Department of Economics, Leiden University, Steenschuur 25, 2311 ES Leiden (o.p.van.vliet@law.leidenuniv.nl) (orcid.org/ 0000-0002-5539-1761). Earlier versions of this paper were presented at the 7th ECPR-SGEU conference in The Hague, 5-7 June 2014, the LIS Summer Workshop in Luxembourg, 29 June to 5 July 2014, the 26th SASE Annual Conference in Chicago, 10-12 July 2014, the 73rd MPSA Annual Conference in Chicago, 16-19 April 2015, and the IBS Jobs Conference in Warsaw, 27-28 October 2015. The authors thank all the participants, Ben Ansell, Michael Blauberger, Koen Caminada, Robert Chalwell, Kees Goudswaard, Brian Nolan, John Peters, David Rueda, Vera Troeger, and two anonymous referees for their helpful comments and suggestions. All errors remain the authors. To view supplementary material and Harvard Dataverse information for this article, please visit https://doi.org/10.1017/psrm.2017.35
} 
Huber and Stephens (2014) do not find significant effects of total imports and exports as a percentage of GDP on earnings inequality. Yet, these studies do not devote specific attention to China's rise on the global economic stage. In addition, trade is measured at the country level even though there are substantial differences in the degree to which sectors within countries are exposed to trade. Furthermore, an important theoretical channel through which trade has an impact on labor market outcomes is neglected. Traditional measures of trade only capture direct linkages between trading partners. These approaches disregard that exporting sectors are also affected by the rise of China when foreign export markets switch to Chinese imports instead.

Recent studies in international economics and labor economics reveal strong distributive effects of the rise of China on the global economy in single-country studies. Autor et al. (2013) and Autor et al. (2015) find that rising Chinese import competition on US labor markets has reduced employment and wages in manufacturing sectors. For Norway, Balsvik et al. (2015) find also negative employment effects, but no indications of wage effects. These authors attribute these dissimilarities in results to the lower flexibility of Norwegian labor market institutions compared to the United States. Although these case studies insightfully depict country-specific developments, they do not allow for a general assessment of labor market outcomes of Chinese trade competition across a broader group of OECD countries with diverse political-economic institutions. Therefore, the research question of the present study is how to explain the variation in employment across sectors and over time.

We aim to complement our existing knowledge of determinants of the distribution of labor market outcomes by analyzing the developments in sectoral employment size and the share of hours worked by low-skilled workers in 17 sectors across 18 OECD countries between 1990 and 2007. In our analysis, we look at the manufacturing industry, which consists of the sectors that are most exposed to Chinese trade competition. On average across our sample, 23 percent of all workers are employed in these sectors, making it a vital part of the economy and society.

We focus on trends in employment for two reasons. First, the distribution of hours worked across skill groups distils employment effects, whereas indicators of total earnings inequality, defined as hours worked times the hourly wage, would mix wage and employment effects. The distribution of hours worked accounts for an important part of total earnings inequality in developed countries, and its importance is increasing over time (Checchi et al. 2016). Second, for employment we have internationally comparable time series data on both trends in the relative amount of employment as well as the distribution of employment across skill groups at the sectoral level.

This approach allows us to examine the distributive effects of Chinese trade competition, while we can account for institutions found to be relevant in the comparative political economy literature (e.g., Rueda and Pontusson 2000; Mahler 2004). With respect to this literature, we seek to make three contributions.

First, existing comparative political economy research pertains to distributive effects of international trade in general, but does not devote attention to effects of Chinese trade in particular. This is remarkable given the importance of employment loss and inequality in labor market outcomes in the real world politics. We empirically test whether increased Chinese trade competition is associated with lower employment and lower shares of working hours for the low-skilled, in order to contribute to our knowledge on determinants of rising levels of earnings inequality in Western countries (Huber and Stephens 2014). Second, we extend our analysis of trade effects by taking into account Chinese competition on foreign export markets. This route of trade competition has been neglected thus far in the existing inequality literature. Third, we take the sector as the unit of analysis. Exposure to international trade and therefore its labor market effects vary substantially across sectors (Hays 2009; Walter 2010; Oesch 2013; 
Thewissen et al. Forthcoming). Our central hypothesis is that sectors with greater exposure to Chinese trade competition experience stronger labor market effects. Furthermore, our study is complementary to recent research on deindustrialization in political science. We inspect the evolution of the manufacturing sectors in detail, while recent accounts mainly focus on developments in the services sectors (Rehm 2009; Wren 2013; Dancygier and Walter 2015).

\section{LITERATURE AND HYPOTHESES}

Our theoretical understanding of the distributive effects of Chinese exports is based on two standard trade models from international economics. In the Ricardo-Viner model, sectors are the central unit of analysis as it is assumed that factor mobility is limited. Employees in sectors with higher exports as a result of the reduction of trade restrictions benefit, whereas employees in sectors with increased imports loose (Samuelson 1971; Hays 2009). In contrast, the StolperSamuelson model, in which factor mobility is assumed to be perfect, hinges on factor endowments (Stolper and Samuelson 1941). Owners of abundant production factors profit from trade.

Increased trade competition stemming from China may affect workers in OECD countries in two ways. First, Chinese imports in OECD countries can substitute the domestic production of goods, resulting in a reduced labor demand. Hence, it can be expected that sectors with more Chinese exports experience more shedding of labor. The findings of Autor et al. (2013) and Balsvik et al. (2015) for respectively the United States and Norway support this hypothesis. Second, Chinese exports may also affect sectors by generating increased competition in the foreign markets where sectors sell their products. As an example, it could be that a German manufacturer has a large market share in France, but sees its exporting opportunities to France decline as France substitutes German imports for Chinese products (Balsvik et al. 2015). Thus, we hypothesize that the relative employment size of sectors more exposed to Chinese trade competition will shrink.

Within sectors, we predict that labor market effects of Chinese trade competition are not equally shared across all workers. Given the relative abundance of low-skilled labor in China, mainly the low-skilled employees in exposed manufacturing sectors in OECD countries will be affected by Chinese exports. Therefore, we hypothesize that within sectors, sectoral exposure to Chinese trade competition is associated with relatively less work for low-skilled employees. For high-skilled workers, however, expectations are less clear-cut. Based on an empirical analysis for the United Kingdom, Bloom et al. (2016) find positive wage effects of Chinese trade competition for highskilled workers. As more competition from China does not imply more exports to China, on the contrary, these positive effects are not an indication of the typical winners from the StolperSamuelson model. Instead, according to recent insights from international economics (e.g., Melitz 2003), increased competition triggers firms to increase their productivity in order to survive. Indeed, Bloom et al. (2016) find that Chinese trade competition has a positive impact on innovation and productivity. In order to achieve this, firms hire more high-skilled workers. This increased demand can be expected to lead to positive labor market effects for high-skilled workers in sectors that are more exposed to Chinese competition.

Another explanation for employment loss and rising levels of labor market inequality is technological change. According to Frey and Osborne (2013), automation of jobs puts 47 percent of total US employment at risk. Moreover, within sectors these employment effects are not equally shared among skill groups according to the so-called skill-biased technological change (Goldin and Katz 2008; Oesch 2013; Wren 2013). Technological innovation complements the high-skilled, while it substitutes routine labor by capital. The demand for high-skilled 
labor increases, leading to better labor market opportunities for highly educated workers. In contrast, the demand for low-skilled labor decreases, resulting in fewer jobs and lower wages for workers with low levels of education. These effects of technological change are supported by empirical studies on the US (Goldin and Katz 2008). Focusing on the labor market effects of information and communication technologies (ICT), Michaels et al. (2014) extend this empirical evidence to sectors in Japan and nine European countries. We hypothesize that exposure to technological change is associated with less employment for low-skilled and more employment for high-skilled labor within sectors. With regard to the overall employment level of a sector, we expect that technological progress is associated with automation of work, and hence a lower relative employment size.

A third line of explanations for the variation in labor market outcomes emphasizes the importance of labor market institutions. As employers and employees bargain over wages and other working conditions, the outcomes of these negotiations are a function of a country's system of labor relations and political power distributions (Huber and Stephens 2014). First, the share of employees covered by wage bargaining agreements and the level of coordination of wage bargaining may affect labor market outcomes. The main hypothesis on this score is that centralized wage bargaining creates fewer and smaller wage differentials as more firms and industries are covered by the same wage settlements (Wallerstein 1999; Rueda and Pontusson 2000; Mahler 2004). Through these wage compression effects, the bargaining coverage and coordination of bargaining may also affect the employment distribution. High-wage settlements may have adverse effects on employment if wages are not in line with productivity. Hence, as multiple sectors are involved in the bargaining, the resulting wage settlement may harm employment in low-productivity sectors (Iversen and Wren 1998).

Furthermore, labor market outcomes may be influenced by employment protection legislation (EPL) and unemployment benefit schemes. It can be expected that EPL protects especially the workers with low levels of education because of a substantial component of fixed costs (Koeniger et al. 2007). As to unemployment benefits, these increase the reservation wage of workers. Hence, generous unemployment benefits exert a positive effect on wages, especially on wages at the lower end of the wage distribution. These higher wages could go hand-in-hand with lower employment possibilities for low-skilled workers.

Finally, the political ideology of governments might also have an impact on the distribution of labor market outcomes. First, since governments are extensively involved in private-sector wage setting in many advanced industrial countries, the ideology of governments might have a direct effect on inequality. Hence, left-wing governments can be expected to pursue policies protecting the low-skilled compared to liberal or conservative governments (Wallerstein 1999). Second, governments might influence labor market outcomes through minimum wage legislation, taxes, and other forms of income policies. Again, it may be expected that left-wing governments adopt policies that lead to less inequality (Rueda and Pontusson 2000; Pontusson et al. 2002; Oliver 2008).

DATA, MEASURES, AND METHOD

\section{Dependent Variables}

We use two main dependent variables and data from multiple sources. ${ }^{1}$ First, we analyze sectoral employment effects, using the relative employment size. This measure is defined as the

\footnotetext{
${ }^{1}$ Table A1 in the Online Appendix contains descriptives for the variables of our main empirical specifications.
} 
number of individuals engaged (employees and self-employed) in a sector divided by the number of individuals engaged in the national economy. As this measure is defined as a share of total employment, it captures employment effects or inequality between sectors. Data are taken from the EU-KLEMS (2007) database. ${ }^{2}$

As our second dependent variable, we analyze the hours worked by low-skilled workers as a share of the total hours worked. ${ }^{3}$ This measure has been used in other studies (OECD 2011a; Michaels et al. 2014). The low-skilled shares are interpreted here as tapping into the employment distribution between skilled and low-skilled workers, since they are also influenced by changes in the hours worked of the high-skilled through the denominator. The data come from the EU-KLEMS March 2008 release.

We focus on employment effects as a key component of earnings inequality for two reasons. First, for employment we can examine both the relative size, for example, the relative amount of employment in exposed sectors, as well as the distribution of employment across skill groups. Second, for employment the EU-KLEMS contains a more distilled indicator of earnings inequality. The data set also has wage bill share information analogous to our hours worked measure, but this indicator mixes wage and employment effects, making it impossible to attribute the effects to either employment or wages. ${ }^{4}$ Using a decomposition analysis, Checchi et al. (2016) find that dispersion in hours worked accounts for up to 40 percent of total earnings inequality in their sample of the United States, United Kingdom, Germany, and France between 1989-2012. Moreover, the authors find that the contribution of the distribution of hours worked is growing over time.

The analysis focuses on 17 sectors at the two-digit International Standard Industrial Classification (ISIC) 3.1 level $^{5}$ across 18 capitalist countries $^{6}$ and utilizes annual data for the years 1990-2007.

\section{Measuring Chinese Trade Competition}

For our measure of exposure to Chinese import competition, we follow existing sectoral studies (Mahler et al. 1999; Michaels et al. 2014) and measure this as the value of the total imported goods as a share of the value added for sector $i$ in country $j$ in year $t$. This measure is the sectoral equivalent of imports as a share of GDP at the country level. ${ }^{7}$ Data on imports come from the OECD (2011b) STAN Bilateral Trade Database and value added is taken from EU-KLEMS (2007).

\footnotetext{
${ }^{2}$ For Canada we have to use the EU-KLEMS March 2008 data set.

3 Table A2 in the Online Appendix shows how "low-skilled" is defined across countries in the EU-KLEMS data set.

${ }^{4}$ The wage bill share has been analyzed by Michaels et al. (2014) and Bloom et al. (2016). Table A4 in the Online Appendix shows that with the wage bill share for the low-skilled we end up with essentially the same results as with the share of hours worked for the low-skilled. The only differences are that the unemployment benefit replacement rate becomes positive and significant, and the unemployment rate negative and significant. Also the size of the coefficients of interest is very comparable.

5 See Table A3 in the Online Appendix for the ISIC codes. We leave out total manufacturing; and manufacturing of chemical, rubber, plastics, and fuel products $(23 \mathrm{t} 25)$ in our descriptives and regressions to avoid having sectoral overlap, as we include all constituent sectors separately.

6 Australia, Austria, Belgium, Canada, Czech Republic, Germany, Denmark, Spain, Finland, France, the United Kingdom, Ireland, Italy, Japan, the Netherlands, Portugal, Sweden, and the United States.

7 As a simple test we calculate the correlation between total imports in value added at the country level from our database and imports of goods and services in percentages of GDP from World Bank National Accounts. The correlation is 0.93 , with a comparable mean (32.0 versus 35.2 from the World Bank) and SD (both 17.5).
} 
To capture the Chinese competition in foreign markets $p$ to which sectors export their goods, export competition for sector $i$ in country $j$ at time $t$ is measured as follows:

$$
\sum_{p}\left(\frac{\text { Exports }_{i j p t}}{\text { Exports }_{i j t}} \times \frac{\left(\text { Chinese exports }_{i p t}-\text { Exports }_{i j p t}\right)}{\text { Total exports }}{ }_{i p t}\right)
$$

The second part of Equation 1 measures the difference in exports from the sector type $i$ of China and country $j$ to country $p$, relative to the total exports-from all countries-of sector type $i$ to country $p .{ }^{8}$ Hence, this measure indicates the difference between the export market shares of the sectors $i$ from China and country $j$ in country $p$. Subsequently, the pressure from the Chinese competition in the foreign market $p$ depends on the relative importance of foreign market $p$ for sector $i$ in country $j$. Therefore, the competition in foreign market $p$ is weighted by the first term of Equitation 1, which is the value of the exported goods from sector $i$ in country $j$ to country $p$ divided by the total exports of sector $i$ in country $j .{ }^{9}$ An advantage of the export competition measure used in this study over the measures used by Autor et al. (2013) and Balsvik et al. (2015), is that our measure accounts for the temporal variation in the exports from sector $i$ in country $j$, whereas the other measures only include the initial market share of this sector. For the export competition measure, sectoral data from the OECD STAN Bilateral Trade Database are collected for 59 partner countries $p$, including all OECD countries, all European countries, the BRIICS, Malaysia, Pakistan, the Philippines, and Thailand, which amounts to little over half a million observations, covering around 85 percent of all imports for our sample of countries.

In Figure 1 we display our measures of import competition and competition in foreign export markets graphically. As an example, we take an industry in Germany. The double lined arrow on the right-hand side pointing upwards shows the exposure to import competition for this industry, coming from (direct) imports from China. The pivoted arrows on the left-hand side together show the amount of export competition. The two solid arrows are the exports from the German and Chinese sector industry to the same industry in the Netherlands. The difference between these Chinese and German exports to the Netherlands, weighted by total exports to the Netherlands, measures the amount of export competition the German sector experiences from China in the Netherlands. This is calculated for more countries, such as France (the dashed lines), and 57 other countries (the dotted lines).

Figure 2 and Table 1 show that China is becoming an increasingly important trading partner for advanced industrialized countries. Figure 2 presents averages for all sectors, whereas

\footnotetext{
${ }^{8}$ We restrict our analysis to 59 partner countries as data for other countries contain too many missings. We calculate Chinese exports to each of the 59 partner countries at the sectoral level for our sample of countries individually as follows. We collect both export data reported by China at the sectoral level, and import data reported by each of the 59 partner countries at the sectoral level. The correlation between the two is 0.99 . To maximize data availability, we first interpolate both time series. Next, we extrapolate the export data from China using the trend in import data from the separate partner countries. As a final check we calculate the percentage of (unweighted) values at the country partner sector year level larger than +1 and smaller than -1 . These numbers would be the result of data differences in the combination of bilateral trade from multiple reporting countries, as it is substantively impossible that the difference between Chinese and home country's exports to a partner's sector divided by total exports to this partner's sector is larger than 1 . The 0.2 percent of all observations for which this is the case are changed to missings.

9 We make two amendments to this weighting factor to make sure it adds to 1 at the sector country year level. First, we multiply the weighting factor by the difference between total country exports and the sum of country exports to each individual country, since we "only" collect data for 59 countries rather than to all countries. Second, for each indicator separately we correct for missing trade information from a partner country, which is only a minor adjustment (the correlation between the corrected and uncorrected series is above 0.97).
} 


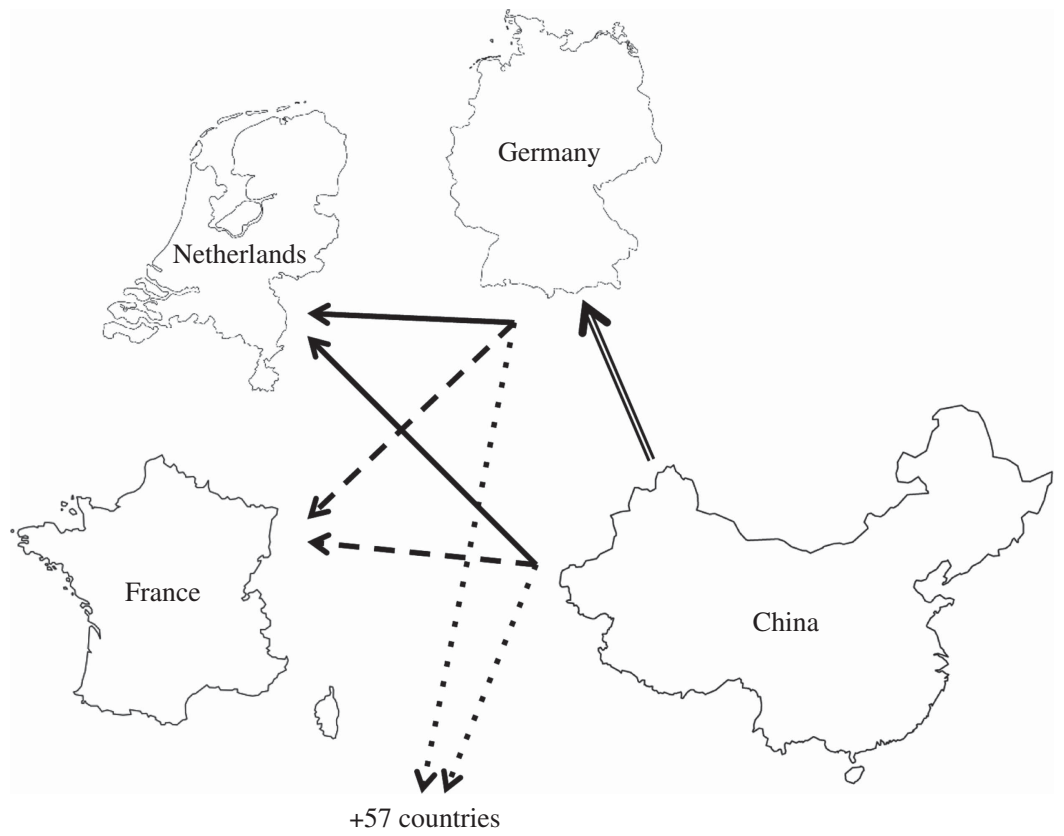

Fig. 1. Import competition and competition in foreign export markets illustrated for a German industry
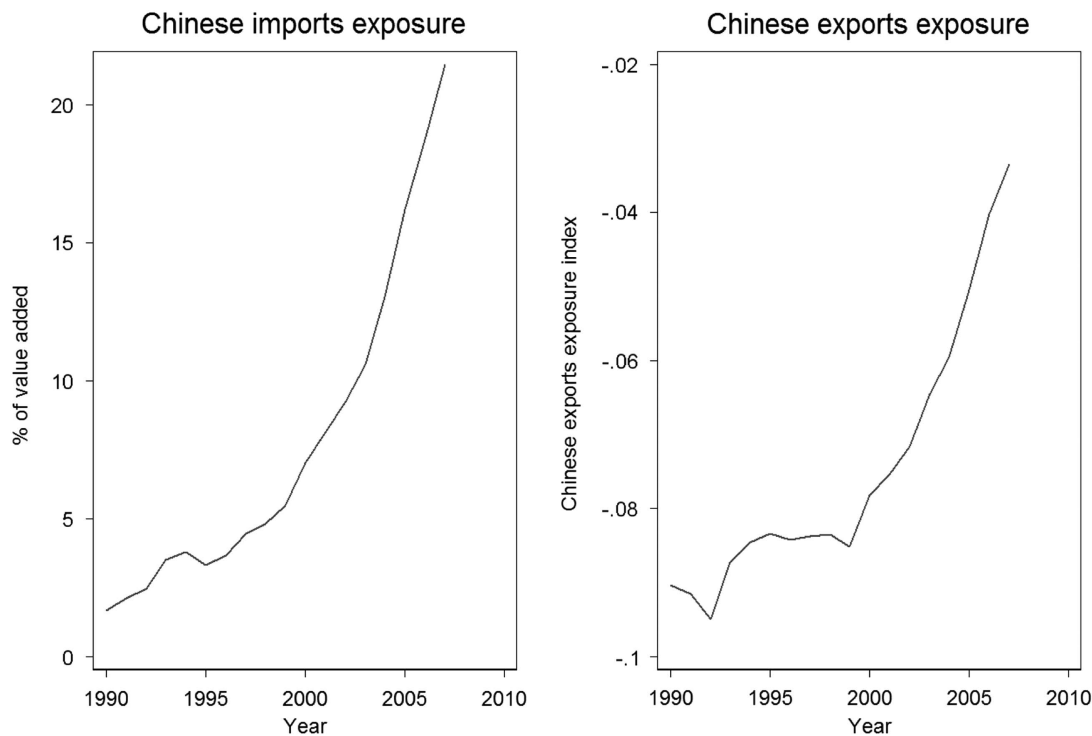

Fig. 2. Evolution of Chinese imports and exports competition

Note: unweighted averages across all countries and sectors in our sample.

Table 1 presents trade exposure per sector averaged across countries. Between 1990 and 2007, the imports from China as a percentage of value added increased in all sectors but the mining industry. The export competition measure shows negative values for all sectors in 1990. This indicates that in the foreign markets, the value of the exports from the OECD countries is on 
TABLE $1 \quad$ Imports and Exports Exposure

\begin{tabular}{|c|c|c|c|c|c|c|}
\hline \multirow[b]{2}{*}{ Sectors } & \multicolumn{3}{|c|}{$\begin{array}{c}\text { Exposure to Imports from China } \\
\text { (\% Value Added })\end{array}$} & \multicolumn{3}{|c|}{ Chinese Exports Exposure (Index) } \\
\hline & 1990 & 2007 & Change & 1990 & 2007 & Change \\
\hline Agriculture & 0.4 & 0.7 & 0.3 & -0.08 & -0.08 & 0.00 \\
\hline Mining & 3.4 & 3.0 & -0.4 & -0.03 & -0.05 & -0.01 \\
\hline Total man. & 1.1 & 16.2 & 15.1 & -0.09 & 0.00 & 0.09 \\
\hline Man. food & 0.6 & 1.7 & 1.1 & -0.08 & -0.07 & 0.00 \\
\hline Man. Textiles & 10.4 & 128.6 & 118.2 & -0.04 & 0.11 & 0.15 \\
\hline Man. wood & 1.1 & 9.1 & 8.0 & -0.10 & -0.05 & 0.05 \\
\hline Man. paper & 0.1 & 1.9 & 1.8 & -0.13 & -0.12 & 0.01 \\
\hline Man. coke, chemicals, rubber & 0.7 & 6.2 & 5.5 & -0.09 & -0.06 & 0.03 \\
\hline Man. coke & 0.5 & 2.0 & 1.5 & -0.10 & -0.12 & -0.03 \\
\hline Man. chemicals & 0.8 & 6.2 & 5.4 & -0.08 & -0.05 & 0.03 \\
\hline Man. rubber & 0.8 & 12.0 & 11.3 & -0.12 & -0.05 & 0.08 \\
\hline Man. other non-metal & 0.5 & 7.2 & 6.7 & -0.11 & -0.02 & 0.09 \\
\hline Man. basic metals & 0.4 & 9.3 & 8.9 & -0.10 & -0.03 & 0.07 \\
\hline Man. machinery & 0.6 & 17.3 & 16.7 & -0.10 & -0.01 & 0.09 \\
\hline Man. electrical & 1.3 & 75.7 & 74.4 & -0.08 & 0.08 & 0.16 \\
\hline Man. transport equipment & 0.1 & 5.4 & 5.3 & -0.13 & -0.08 & 0.05 \\
\hline Man. n.e.c & 4.3 & 41.9 & 37.7 & -0.07 & 0.04 & 0.11 \\
\hline Average (unweighted) & 1.7 & 21.5 & 19.8 & -0.09 & -0.03 & 0.06 \\
\hline
\end{tabular}

Note: Man. = manufacturing.

Source: Trade data from OECD (2011b) STAN Bilateral Trade Database, value added from EU-KLEMS (2007)

average larger than the value of the Chinese exports. Over time, the exposure to Chinese competition has rapidly increased for exporting firms, as indicated by less negative values.

Interestingly, the exposure to import and export competition from China varies considerably across sectors. This is also reflected by a low correlation between the two measures (0.25). For instance, exposure to Chinese export competition in the electrical manufacturing sector increased between 1990 and 2007, whereas it hardly changed in the paper industry. However, exposure to Chinese imports in the home markets did increase substantially in the paper industry.

\section{Other Independent Variables}

We include a measure of total imports excluding Chinese imports as a share of sectoral value added to account for the effects of other imports. Chinese imports and total imports excluding Chinese imports are substantively and empirically distinct, as indicated by a low correlation $(0.14)$ and a much more rapid rise of Chinese imports (15.2 instead of 2.0 percent on average per year for our sample).

To account for effects of skill-biased technological change on employment, we follow Michaels et al. (2014), Massari et al. (2013), and Wren (2013) and include ICT capital compensation as a share of sectoral value added from the EU-KLEMS (2007) dataset. ${ }^{10}$ As international trade and skill-biased technological change affect labor market outcomes given a certain labor supply (Goldin and Katz 2008), we also account for the heterogeneity in the

\footnotetext{
${ }^{10}$ As Michaels et al. (2014) also note, since capital compensation is calculated as a residual, it could be negative. We replace values by zeros if negative (3 percent of total observations). We calculate the indicator by multiplying ICT capital compensation as a share of total capital compensation by capital compensation, and divide this by value added. We have to use the EU-KLEMS March 2008 version for Portugal.
} 
relative skill supply across countries. We use the percentage of the total population with tertiary education completed from Barro and Lee (2015).

To account for wage-setting institutions, we include the bargaining coverage, defined as the proportion of employees covered by wage bargaining agreements, and the level of wage coordination. Both measures are taken from the ICTWSS database (Visser 2013). ${ }^{11}$ We use two measures for the strictness of EPL, both taken from the OECD (2014a). We take the EPL strictness index for regular contracts, and the index for temporary employment. For unemployment benefit schemes, we take replacement rates from Van Vliet and Caminada (2012). ${ }^{12}$ To analyze the impact of left-wing governments, we use the percentage of total cabinet posts held by left-wing parties from the Comparative Political Data Set (Armingeon et al. 2012).

To control for cyclical dynamics (Thewissen 2014), we include the sectoral volume of gross value added. Data are taken from the EU-KLEMS (2007) data set. To control for more general economic conditions at the country level, we include the unemployment rate. Unemployment rates are taken from the OECD (2014b) Labour Force Statistics. Finally, we include real GDP per capita from the OECD (2014c) National Accounts.

\section{Method}

The error correction model (ECM) has become a conventional estimator in studies on pooled time series cross-section data. The model is able to capture both long-term structural effects and short-term transitory effects (De Boef and Keele 2008). Recently, the use of ECMs has become subject of debate. Grant and Lebo (2016) argue that ECMs are problematic if equations are unbalanced or if data are stationary. Keele et al. (2016) agree on the point of unbalanced equations, but they maintain - as in De Boef and Keele (2008) - that ECMs can be applied to stationary and non-stationary data alike. Indeed, we find evidence for non-stationarity in our data. ${ }^{13}$ An ECM can be applied in case of non-stationarity, if there is evidence of cointegration within the model (Grant and Lebo 2016). We test for model cointegration with a three-step procedure. First, we run a static model. Second, we predict the residuals from this model. Third, we run the model specified in first differences in which we include the predicted residuals - the error correction term.

The coefficient of the error correction term is negative and strongly significant for the relative employment size and the share of hours worked by low-skilled workers. Therefore, we rely on ECMs for our main estimations. The estimated equation of the ECM is:

$$
\Delta y_{i j t}=\alpha_{0}+\alpha_{1} y_{i j t-1}+\beta_{0} \Delta X_{i j t}+\beta_{1} X_{i j t-1}+\beta_{2} z_{i t-1}+\gamma_{i}+\varepsilon_{i j t}
$$

Here, $\Delta \mathrm{y}_{\mathrm{ijt}}$ denotes the first difference in the dependent variable in sector $i$ in country $j$ and year $t ; \alpha_{0}$ the intercept, and $\varepsilon$ the error term. For the vector of independent variables $x$ the short-term effects are indicated by $\beta_{0}$. The long-term effects are indicated by $\beta_{1} /-\alpha_{1}$. Unit fixed effects $\gamma_{i}$ are included to account for unobserved sector-specific heterogeneity. ${ }^{14}$

\footnotetext{
${ }^{11}$ For Ireland, we use the third ICTWSS version and we interpolate the data.

12 We linearly interpolate bargaining coverage rates, percentages of the population with tertiary education, and replacement rates.

13 We conduct Im-Pesaran-Shin tests for each of our time series individually, where the time trend and a lag structure are allowed to differ across time series. The lion's share of our time series suffers from non-stationarity. Further tests show that first differencing our variables removes the persistence in the majority of the time series for our variables.

14 The combination of a lagged dependent variable and unit fixed effects introduces inconsistency to our model (the Nickell 1981 bias). For our panel with relatively long time series $(T=18)$ this bias will be small and
} 
Given the fact that the recent debate has highlighted some important weaknesses of ECMs (Grant and Lebo 2016; Keele et al. 2016), we also estimate partial adjustment models. As will be discussed below, the partial adjustment models yield highly comparable results. The estimated equation of the partial adjustment model is:

$$
y_{i j t}=\alpha_{0}+\alpha_{1} y_{i j t-1}+\beta_{0} X_{i j t}+\beta_{1} z_{i t}+\gamma_{i}+\varepsilon_{i j t}
$$

Despite the fact that the lagged dependent variable absorbs autocorrelation in the error term, Breusch-Godfrey tests indicate that there is still autocorrelation left. Therefore, the error term is specified to follow a panel-specific AR(1) process. In addition, we use panel-corrected standard errors to correct for panel-heteroskedasticity and contemporaneous spatial correlation (Beck and Katz 2011).

\section{EMPIRICAL ANALYSIS}

\section{Relative Employment Size}

The estimation results with the relative employment size as dependent variable are presented in Table 2. This variable is measured as the number of people working in a sector divided by people working in the national economy. As this ratio sums to one for each country-year observation, the country-level variables lose their interpretation and are not included. In terms of significance and magnitude, the results of the ECM (1) are comparable to the results of the partial adjustment model (2). Chinese imports are negatively associated with the relative employment size. This result provides empirical support for the hypothesis that imported Chinese goods substitute domestically produced goods leading to negative employment effects. The employment effects of total imports excluding Chinese imports are comparable but smaller. Exposure to Chinese export competition seems to have a negative effect on the relative employment size, but only in the short run as the coefficient for the lagged level is not significant. ${ }^{15}$

The results indicate a negative association between technological change and the relative employment size of sectors. This suggests that in sectors with rapid technological progress workers have been substituted, resulting in lower relative employment levels. Furthermore, the results provide some evidence for positive employment effects of the value added.

Next, we graphically assess whether the long-term effects of Chinese import competition on the relative employment size are quantitatively important (Williams and Whitten 2012; DiGiuseppe 2015; Clay and DiGiuseppe 2016). ${ }^{16}$ Using the estimates of the partial adjustment model, Figure 3 presents dynamic simulations for Chinese import competition and for technological change for a period of ten years, allowing us to compare the magnitude of the effects of these two independent variables. ${ }^{17}$ The simulations begin with the relative employment size at the sample median. For import competition and technological change, we present two scenarios: a "low scenario" (we hold the value of the covariate at the 5th percentile of the sample)

(Fnote continued)

we chose to ignore it (see Breitung 2015, 455). Leaving out the unit fixed effects leads to fully comparable results, the only exception being that technological change is no longer significant for the relative employment size as dependent variable (results available upon request).

15 It might be that Chinese goods function as substitutes in some sectors and as complements in others. We do not find evidence for this on the basis of interactions of unit fixed effects and Chinese trade variables. Results are available upon request.

${ }_{17}$ We would like to thank Chad Clay and Matthew DiGiuseppe for sharing their Stata-code.

17 For Chinese export competition simulations are shown in Figure A1 in the Online Appendix, since this variable is not significant in the regression results. 
тав LE 2 Chinese Import and Export Competition and Relative Employment Size

(1) Error Correction Model

Dependent Variable: $\Delta$ Relative Employment Size

$\Delta$ Chinese imports $\left(\times 10^{-1}\right)$

Chinese imports $(t-1)\left(\times 10^{-1}\right)$

$\Delta$ Chinese exports competition

Chinese exports competition $(t-1)$

$\Delta$ Total excluding Chinese imports $\left(\times 10^{-1}\right)$

Total excluding Chinese imports $(t-1)\left(\times 10^{-1}\right)$

$\Delta$ Technology

Technology $(t-1)$

$\Delta$ Value added

Value added $(t-1)$

Relative employment size $(t-1)$

Constant

$N$

Adjusted $R^{2}$

(2) Partial Adjustment Model

Dependent Variable: Relative Employment Size

$\begin{array}{llc}-0.294 & & \\ (-1.20) & & -0.293^{* *} \\ -0.261 * & \text { Chinese imports }\left(\times 10^{-1}\right) & (-2.51) \\ (-1.94) & & \\ -0.120^{* *} & & 0.004 \\ (-2.20) & & (0.52) \\ 0.007 & \text { Chinese exports competition } & \\ (1.06) & & \\ 0.001 & & -0.005^{* * *} \\ (0.62) & & (-3.77) \\ -0.003^{* * *} & \text { Total excluding Chinese imports }\left(\times 10^{-1}\right) & \\ (-3.11) & & -0.175^{* * *} \\ -0.168 & & (-2.82) \\ (-1.38) & & \\ -0.141^{* * *} & \text { Technology } & \\ (-2.97) & & 0.000 \\ 0.000 * * * & & (0.63) \\ (2.88) & & 0.962^{* * *} \\ 0.000 & \text { Value added } & (251.73) \\ (0.10) & & 0.001 \\ -0.038^{* * *} & \text { Relative employment size }(t-1) & (0.03) \\ (-10.75) & & 4307 \\ -0.000 & \text { Constant } & 0.997 \\ (-0.03) & & \\ 4270 & N & \\ 0.374 & \text { Adjusted } R^{2} & \end{array}$

Note: Panel-corrected standard errors and panel-specific AR(1) structure, 1990-2007. The regression also includes sector fixed effects (not shown here). $t$-Statistics in parentheses.

$* \mathrm{p}<0.1, * * \mathrm{p}<0.05, * * * \mathrm{p}<0.01$.

and a "high scenario" (in which we take the 95th percentile). ${ }^{18}$ As an illustration, in Canada, manufacturing of paper has a Chinese import competition value around the low scenario, whereas import competition for manufacturing of textiles is around the high scenario value. In the United Kingdom, a low scenario level of technological change can be found in manufacturing of coke, while manufacturing of electrical and optical equipment shows high scenario values. All other variables are held at the sample mean. ${ }^{19}$ The vertical bars indicate 95 percent confidence intervals around the simulated values.

\footnotetext{
${ }^{18}$ Here, we follow Johnson and Schwindt-Bayer (2009) who also take the 5th and 95th percentile for the simulations. We also considered two alternative values for low and high scenarios (results available upon request). First, we place our variables of interest at the 15 th and 85 th percentile. The predicted level of the relative employment size does not differ much between the 5 th and 15 th percentile low scenario. Moving from a 95th to a 85th percentile shock makes the predicted decrease in relative employment size less strong (around 0.97-0.98 percent at $t=10$ years), but still the low and high scenarios significantly diverge over time for import competition (from around $t=5$ years) and for technological change (from $t=1$ year). Second, we define the low scenario by the variables of interest at their mean and the high scenario value as the mean plus one standard deviation. The predicted relative employment size at the mean plus one standard deviation is comparable to the prediction at the 95th percentile. As expected, the predicted relative employment size is lower at the mean as low scenario (around 0.99 percent at $t=10$ years) than at the 5 th percentile. With this alternative specification predicted outcomes for low and high scenarios for both import competition and technological change do not overlap from around $t=2$ onwards.

19 For the industry dummies, we set the industry with median unit fixed effect size to 1 (industry 17 for the estimations of the relative employment size, industry 5 for the hours worked low-skilled) and the rest of the industries to 0 .
} 


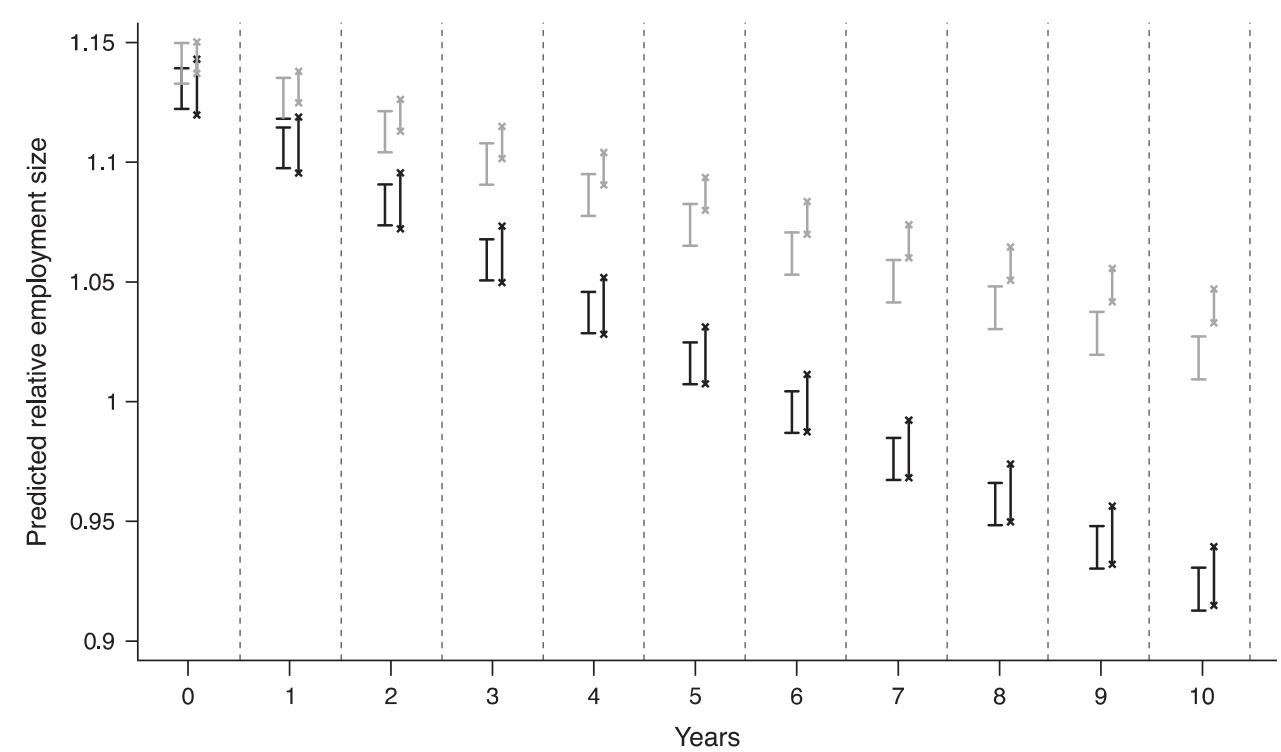

I Import competition - grey at $5 \%$ and black at $95 \%$

Technological change - grey at $5 \%$ and black at $95 \%$

Fig. 3. Simulated long-term effects of Chinese import competition and technological change on relative employment size

Note: vertical lines indicate the $95 \%$ confidence intervals for each year. They are slightly jittered to avoid overlap.

The simulations highlight several aspects. First, for Chinese import competition the 5 percent scenario differs significantly from the 95 percent scenario from $t+1$ (the second vertical bar) onwards, as the bounds of the confidence intervals do not overlap. ${ }^{20}$ Second, within both scenarios, the confidence intervals surpass the boundaries of previous values in the course of time. This indicates the significance of long-term effects of import competition on the relative employment size. Third, the figure shows that the gaps in predicted relative employment size between the two scenarios increase when time progresses. The relative employment size under a 5 percent Chinese import scenario shows a predicted decrease from around 1.14 to 1.02 percent over ten years. For a 95 percent Chinese import scenario, however, the predicted decrease in employment size is 0.10 percentage points larger or the predicted decrease is almost twice as large, to 0.92 percent. Thus, on average for each of the manufacturing sectors, the difference between low and high exposure to Chinese imports matters by an estimated 0.1 percent of total employment over ten years, which seems to be a quantitatively meaningful effect size. ${ }^{21}$

Figure 3 shows that the predicted effects on the relative employment size of Chinese import competition and technological change are very comparable. Also for technological change, the 5 percent scenario becomes statistically significant from the 95 percent scenario from $t+1$ onwards. The bounds of the 95 percent scenario of technological change and Chinese import competition overlap over the entire ten years. For the 5 percent scenario, the bounds overlap for the largest part of the ten years as well.

\footnotetext{
${ }^{20}$ Tests of visually observing overlap of confidence intervals are conservative compared with conventional statistical hypothesis testing (Philips et al. 2016, 273).

21 This simple calculation ignores general equilibrium effects where workers can move to other sectors.
} 
TABLE 3 Chinese Import and Export Competition and Hours Worked Low-Skilled

(3) Error Correction Model

Dependent Variable: $\Delta$ Share Hours Worked Low-Skilled

$\Delta$ Chinese imports $\left(\times 10^{-1}\right)$

Chinese imports $(t-1)\left(\times 10^{-1}\right)$

$\Delta$ Chinese exports competition

Chinese exports competition $(t-1)$

$\Delta$ Total excluding Chinese imports $\left(\times 10^{-1}\right)$

Total excluding Chinese imports $(t-1)\left(\times 10^{-1}\right)$

$\Delta$ Technology

Technology $(t-1)$

$\Delta$ Value added

Value added $(t-1)$

Bargaining coverage $(t-1)$

Bargaining coordination $(t-1)$

Left government $(t-1)$

EPL regular contracts $(t-1)$

EPL temporary contracts $(t-1)$

Unemployment benefits $(t-1)$

Education level $(t-1)$

Unemployment rate $(t-1)$

GDP per capita $\left(\times 10^{-3}\right)(t-1)$

Share hours worked low-skilled $(t-1)$

Constant

$N$

Adjusted $R^{2}$
6.272

(0.95)

$-6.575^{* *}$

$(-2.50)$

$-0.264$

$(-0.19)$

$-1.174^{* * * *}$

$(-3.32)$

$0.146^{* * *}$

(2.17)

$-0.017$

(-0.46)

2.408

(0.91)

$-3.688 * *$

$(-2.51)$

0.000

(0.16)

$-0.001$

$(-0.64)$

$-0.004$

(-1.02)

$-0.128 * *$

$(-2.20)$

0.001

(0.61)

$0.383^{*}$

(1.83)

$-0.072$

$(-0.96)$

0.032

(0.15)

$0.052 * *$

(1.96)

$-0.027$

(-1.55)

$0.013^{*}$

(1.80)

$-0.010^{* * *}$

$(-2.12)$

$-1.405^{* * *} *$

$(-3.65)$

3777

0.185
(4) Partial Adjustment Model

Dependent Variable: Share Hours Worked Low-Skilled

Chinese imports $\left(\times 10^{-1}\right)$

$-3.635^{* *}$

$(-2.46)$

Chinese exports competition

$-1.049^{* * * *}$

$(-3.87)$

Total excluding Chinese imports $\left(\times 10^{-1}\right) \quad 0.016$

(0.30)

Technology

$-2.938^{*}$

$(-1.66)$

Value added

$-0.000$

$(-0.60)$

Bargaining coverage

Bargaining coordination

$(-1.54)$

$-0.154 * *$

$(-2.96)$

Left government

EPL regular contracts

EPL temporary contracts

0.001

$(0.47)$

$0.433 * *$

(2.46)

$-0.058$

$(-0.87)$

Unemployment benefits

0.107

$(0.43)$

Education level

$0.040 *$

(1.75)

Unemployment rate

GDP per capita $\left(\times 10^{-3}\right)$

$-0.025$

$(-1.54)$

$0.018^{* * * *}$

(2.61)

Share hours worked low-skilled $(t-1)$

$0.990 * *$

(239.17)

Constant

$-1.465^{* * *}$

$(-4.03)$

$N$

3814

0.998

Note: Panel-corrected standard errors and panel-specific AR(1) structure, 1990-2004. The regressions also include sector fixed effects (not shown here). $t$-Statistics in parentheses.

$\mathrm{EPL}=$ employment protection legislation .

$* \mathrm{p}<0.1, * * \mathrm{p}<0.05, * * * \mathrm{p}<0.01$.

\section{Hours Worked Low-Skilled}

Table 3 presents the results with the share of the hours worked by low-skilled workers as dependent variable. Again, the ECM and partial adjustment model results are very comparable. Chinese imports and Chinese export competition are negatively associated with the share of hours worked by workers with low levels of education. These results suggest that in sectors more exposed to Chinese trade competition, workers with low levels of education are confronted with negative consequences in their hours worked. Furthermore, the results suggest that total imports excluding Chinese imports are positively associated with the share of the hours 


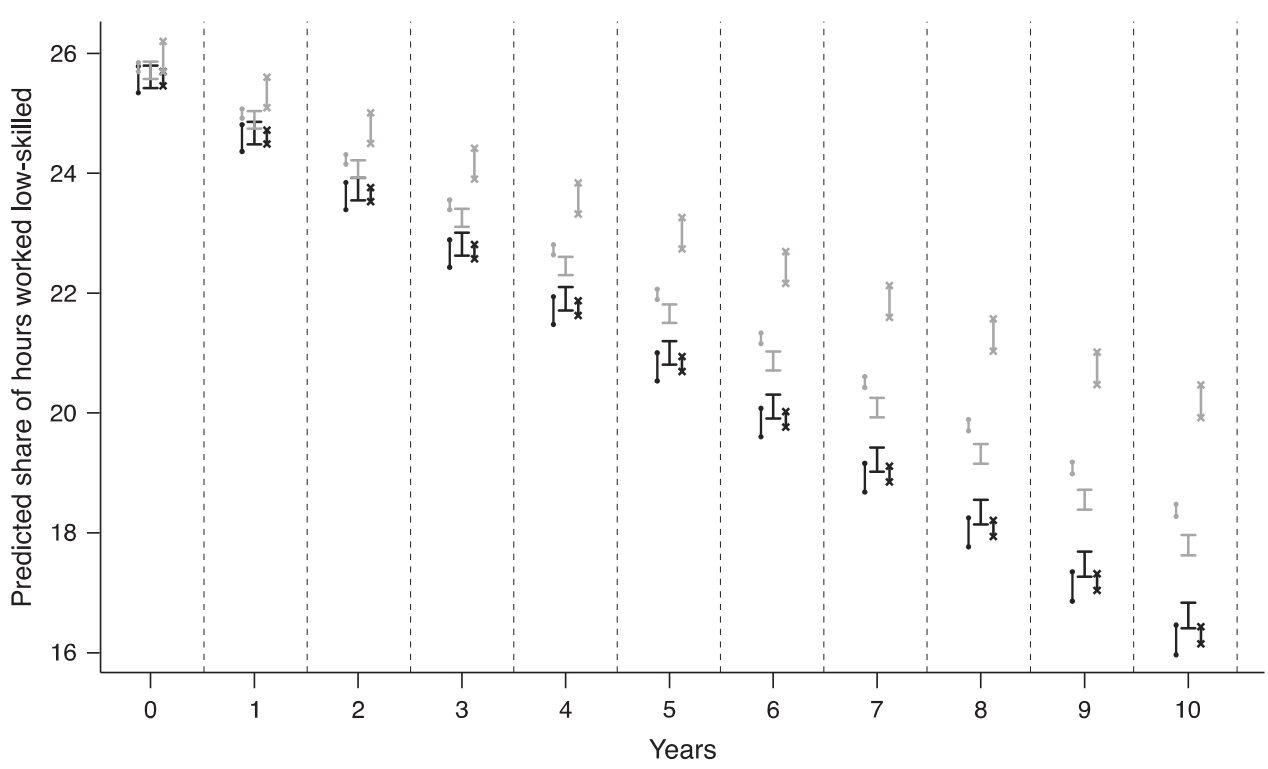

I Import competition - grey at $5 \%$ and black at $95 \%$

Export competition - grey at $5 \%$ and black at $95 \%$

I Technological change - grey at $5 \%$ and black at $95 \%$

Fig. 4. Simulated long-term effects of Chinese import competition, Chinese export competition and technological change on hours worked low-skilled

Note: vertical lines indicate the $95 \%$ confidence intervals for each year. They are slightly jittered to avoid overlap.

worked by low-skilled workers in the short run, as the coefficient for the lagged level is insignificant. $^{22}$

We find a negative association between technological change and the share of hours worked by low-skilled workers. This is in line with the hypothesis that skill-biased technological change negatively affects the employment position of low-skilled workers.

Regarding the institutional variables, we find a negative association for the coordination of wage bargaining. The positive association for EPL for workers with a regular contract suggests that EPL provides primarily protection for low-skilled workers. As to the economic control variables, the education level of the population has a positive association. This could follow from a supply and demand effect, when the increase in relative supply of high-skilled decreases their gains, leading to relative improvements for the lowly educated (Goldin and Katz 2008). Finally, the results provide some evidence for employment effects of GDP per capita.

Subsequently, we assess the long-term effects for the share of hours worked by low-skilled workers based on the estimates of Model 4. Following the same approach as discussed above, Figure 4 illustrates the simulated effects from Chinese import competition, Chinese export competition and technological change, as all three variables are significant. Earlier we gave examples of sectors showing low and high scenarios for import competition and technological change. For export competition, in Canada manufacturing of wood shows low scenario values while manufacturing of textiles displays high scenario values.

\footnotetext{
${ }^{22}$ We again do not find robust results for heterogeneous effects of Chinese trade competition across sectors. Results are available upon request.
} 
For export competition and technological change, the 5 and 95 percent scenarios differ significantly from each other from $t+1$ onwards. For import competition, this is the case from $t+3$ onwards. We again find quantitatively meaningful predicted effect sizes. For the 95 percent scenario the predicted shares of hours worked by the low-skilled are comparable for the three variables, but for the 5 percent scenario there are differences. In year $t+10$, the predicted difference between the 5 and 95 percent scenario is the largest for export competition. A sector experiencing a 5 percent exposure to Chinese export competition scenario has a predicted share of 20.5 percent of hours worked by the low-skilled, compared to a predicted share of 16.5 percent for a sector experiencing 95 percent exposure after ten years. ${ }^{23}$

\section{Sensitivity Analysis}

We perform additional tests to examine the robustness of our results. ${ }^{24}$ First, the rise of the Chinese economy may not only increase the competition for sectors in OECD countries, but could also increase exports of China, which might have positive employment effects. To account for this, we include exports to China as a percentage of value added in our regressions. In ECMs, the coefficients for exports to China are never significant and do not affect the findings as presented above. In the partial adjustment models, exports to China are positively ( $p$-value $<0.1$ ) associated with the relative employment size; other results remain the same.

In addition, we account for other emerging economies to examine the uniqueness of the Chinese trade competition. The sum of imports from India, Malaysia, Mexico, the Philippines, and Thailand-which is lower and grew less than the imports from China-is never significant in the regressions. Apparently, the magnitude of the imports from other emerging economies is too small (still) to find any effects with regression analysis.

Our analysis accounts for a large number of trade and institutional variables that might play a role in labor market outcomes. Following other recent inequality studies (e.g., Michaels et al. 2014) we do not control for international flows of capital as another aspect of globalization (Mahler 2004) or patterns in the minimum wage in our regressions because of limited data availability. We perform additional sensitivity tests where we include bilateral data on foreign direct investment positions, inflows, and outflows, and the minimum wage relative to median or mean wage (OECD 2014b; OECD 2014d). We lose up to two thirds of the observations, and our included variables never reach significance.

\section{CONCLUSIONS}

With the rapid expansion of the Chinese economy, the international trade arena has changed substantially for manufacturing sectors in Western countries in the last two decades. Despite the

\footnotetext{
${ }^{23}$ We again consider alternative values for low and high scenarios (see footnote 20). For these more muted shocks the predicted effect of import competition on share of hours worked by low skilled is lower. First, for a 15 and 85 percent shock the predicted share of hours worked lies around 17.5 percent; overlap between the confidence intervals of the low and high scenarios only disappears from around $t=9$ onwards. The low and high values for export competition still diverge from around $t=1$ onwards, and now predict shares of around 18.5 and 16.5 percent, respectively. These predictions are comparable to those for technological change, for which confidence intervals of low and high scenarios no longer overlap from around $t=3$ onwards. Second, for a mean and mean plus 1 SD scenario comparison, we also find more muted effects. Both for import competition and technological change in the low versus high scenario diverges from around $t=5$ onwards, with predicted outcomes around 17.5 and 16.5 percent at $t=10$ years, respectively. For export competition divergence is shown from around $t=3$ onwards, with predicted outcomes around 17.5 and 16.1 percent.

${ }^{24}$ Results are available upon request.
} 
fact that this surge of China has been subject of debate in many political arenas, to date it has not received much attention in comparative political economy. We contribute to our understanding of the effects of Chinese trade competition by analyzing employment effects for a broad set of advanced industrialized democracies. We use sectoral measures of Chinese trade competition between 1990 and 2007 for 18 countries. Moreover, we include a measure that taps into export competition stemming from China.

Accounting for institutional variation across countries, our analysis shows employment declines in sectors that are more exposed to imports from China. Existing studies report distributive effects of Chinese imports on employment levels in the United States and Norway (Autor et al. 2013; Balsvik et al. 2015). Our study generalizes these findings to a set of 18 OECD countries with diverse labor market institutions.

Within sectors, employment effects are not equally shared across skill levels, as we hypothesized. The results suggest that the low-skilled workers bear the brunt of the substitution of domestic production by Chinese imports. These distributive effects are also shown by the results for the increased competition from China in foreign export markets. Sectors with greater exposure to export competition experience declines in the share of employment for low-skilled workers. These results are in line with the hypothesis that production work of low-skilled workers is substituted by Chinese exports, resulting in a lower demand for low-skilled labor. A wider implication of these results seems to be that current studies where competition for exporting sectors is neglected leads to underestimation of the distributional effects of trade competition.

Skill-biased technological change is often put forward as an additional determinant of the labor market outcomes at hand. Indeed, we find a negative effect of technological change on the relative employment size of sectors. Furthermore, in sectors with greater technological innovation, we find that the relative employment position of low-skilled workers worsens.

With regard to effect sizes, we find evidence indicating that Chinese trade competition has a quantitatively important association with the relative sectoral employment size and the distribution of employment across skill groups. The effect sizes are comparable to those found for technological change, a factor that has attracted wide attention in the academic literature (e.g., Frey and Osborne 2013).

More generally, our study stresses the importance of considering the substantial differences between Chinese imports and overall globalization, and the large variation in exposure across sectors. Theoretically, we would expect trade competition from China to have particularly strong distributive effects given its large volume of low-wage labor. Our empirical evidence supports this. The analysis shows overall employment declines in sectors more exposed to Chinese imports and to the increased Chinese competition in foreign markets. Yet, this association should be interpreted with caution, as our empirical approach does not identify exogenous variation in the main variables.

Nevertheless, our sectoral approach acknowledges the substantial sectoral variation in employment on the one hand, and the exposure to Chinese imports and technological change on the other. Hence, a sectoral approach seems to be a fruitful direction for the analysis of the determinants of the widely observed trend of unequal employment developments across OECD countries over the past decades. Future research could shed more light on individual employment shifts between sectors when detailed micro-level panel data becomes available.

\section{REFERENCES}

Armingeon, Klaus, Laura Knöpfel, David Weisstanner, and Sarah Engler. 2012. Comparative political data set III 1990-2012. Bern: University of Bern. 
Autor, David, David Dorn, and Gordon Hanson. 2013. 'The China syndrome: Local labor market effects of import competition in the United States'. American Economic Review 103(6):2121-168.

Autor, David, David Dorn, and Gordon Hanson. 2015. 'Untangling trade and technology: Evidence from local labor markets'. The Economic Journal 125(584):621-46.

Balsvik, Ragnhild, Sissel Jensen, and Kjell Salvanes. 2015. 'Made in China, sold in Norway: Local labor market effects of an import shock'. Journal of Public Economics 127:137-44.

Barro, Robert, and Jong-Wha Lee. 2015. Barro-Lee educational attainment data, July 2015 update, http:// barrolee.com, accessed 3 March 2014.

Beck, Nathaniel, and Jonathan Katz. 2011. 'Modeling dynamics in time-series-cross-section political economy data'. Annual Review of Political Science 14:331-52.

Bloom, Nicholas, Mirko Draca, and John Van Reenen. 2016. 'Trade induced technical change? The impact of Chinese imports on diffusion, innovation, and productivity'. Review of Economic Studies 83(1):87-117.

Breitung, Joerg. 2015. 'The analysis of macroeconomic panel data'. In: Badi H. Baltagi ((ed.)), The Oxford handbook of panel data, 453-92. Oxford: Oxford University Press.

Checchi, Daniele, Cecilia García-Peñalosa, and Lara Vivian. 2016. 'Are changes in the dispersion of hours worked a cause of increased earnings inequality?'. IZA Journal of European Labor Studies $5(15): 1-34$.

Clay, K. Chad, and Matthew R. Digiuseppe. 2016. The physical consequences of fiscal flexibility: Sovereign debt and physical integrity right, British Journal of Political Science, 47(4): 783-807.

Dancygier, Rafaela, and Stefanie Walter. 2015. 'Globalization, labor market risks, and class cleavages'. In: Pablo Beramendi, Silja Häusermann, Herbert Kitschelt and Hanspeter Kriesi ((eds.)), The politics of advanced capitalism, pp. 133-56. Cambridge: Cambridge University Press.

De Boef, Suzanna, and Luke Keele. 2008. 'Taking time seriously'. American Journal of Political Science 52(1):184-200.

DiGiuseppe, Matthew R. 2015. 'Guns, butter and debt: Sovereign creditworthiness and military expenditure'. Journal of Peace Research 52(5):680-93.

EU-KLEMS. 2007. EU KLEMS Growth and Productivity Accounts (Versions 1.0, November 2009, March 2011) http://www.euklems.net/data/EUKLEMS_Growth_and_Productivity_Accounts_Part_I_ Methodology.pdf, accessed 3 March 2014.

Frey, Carl Benedikt, and Michael Osborne. 2013. The future of employment: How susceptible are jobs to computerisation?, Oxford Martin School Working Paper, Oxford

Goldin, Claudia, and Lawrence Katz. 2008. The race between education and technology. Cambridge: Harvard University Press.

Grant, Taylor, and J. Lebo Matthew. 2016. 'Error correction models with political time series'. Political Analysis 24(1):3-30.

Hays, Jude. 2009. Globalization and the new politics of embedded liberalism. Oxford: Oxford University Press.

Huber, Evelyne, and John Stephens. 2014. 'Income inequality and redistribution in post-industrial democracies: demographic, economic and political determinants'. Socio-Economic Review 12(2): 245-267.

Iversen, Torben, and Anne Wren. 1998. 'Equality, Employment and budgetary restraint: The trilemma of the service economy'. World Politics 50(4):507-46.

Johnson, Gregg B., and Leslie A. Schwindt-Bayer. 2009. 'Economic Accountability in Central America'. Journal of Politics in Latin America 1(3):33-56.

Keele, Luke, Suzanna Linn, and Clayton Webb. 2016. 'Treating Time with all Due Seriousness'. Political Analysis 24(1):31-41.

Koeniger, Winfried, Marco Leonardi, and Luca Nunziata. 2007. 'Labor market institutions and wage inequality'. Industrial and Labor Relations Review 60(3):340-56.

Mahler, Vincent. 2004. 'Economic globalization, domestic politics, and income inequality in the developed countries: A cross-national study'. Comparative Political Studies 37(9):1025-053. 
Mahler, Vincent, David Jesuit, and Douglas Roscoe. 1999. 'Exploring the impact of trade and investment on income inequality: A cross-national sectoral analysis of the developed countries'. Comparative Political Studies 32(3):363-95.

Massari, Riccardo, Paolo Naticchioni, and Giuseppe Ragusa. 2013. 'Unconditional and conditional wage polarization in Europe'. NEUJOBS Working Paper no. D3.6, Rome.

Melitz, Marc. 2003. 'The impact of trade on intra-industry reallocations and aggregate industry productivity'. Econometrica 71(6):1695-725.

Michaels, Guy, Ashwini Natraj, and John Van Reenen. 2014. 'Has ICT polarized skill demand? Evidence from eleven countries over 25 years'. Review of Economics and Statistics 96(1):60-77.

Nickell, Stephen. 1981. 'Biases in dynamic models with fixed effects'. Econometrica 49(6):1417-426.

OECD. 2011a. Divided we stand: Why inequality keeps rising. Paris: OECD.

OECD. 2011b. STAN structural analysis database. Paris: OECD.

OECD. 2012. Policy priorities for international trade and jobs. Paris: OECD.

OECD. 2014a. Indicators of employment protection. Paris: OECD.

OECD. 2014b. Labour force statistics. Paris: OECD.

OECD. 2014c. National accounts. Paris: OECD.

OECD. 2014d. International direct investment database. Paris: OECD.

Oesch, Daniel. 2013. Occupational change in Europe: How technology \& education transform the job structure. Oxford: Oxford University Press.

Oliver, Rebecca. 2008. 'Diverging developments in wage inequality: Which institutions matter?'. Comparative Political Studies 41(12):1551-582.

Philips, Andrew Q., Amanda Rutherford, and Guy D. Whitten. 2016. 'Dynamic pie: A strategy for modeling trade-offs in compositional variables over time'. American Journal of Political Science 60(1):268-83.

Pontusson, Jonas, David Rueda, and Christopher Way. 2002. 'Comparative political economy of wage distribution: The role of partisanship and labour market institutions'. British Journal of Political Science 32(2):281-308.

Rehm, Philipp. 2009. 'Risks and redistribution: An individual-level analysis'. Comparative Political Studies 42(7):855-81.

Rueda, David, and Jonas Pontusson. 2000. 'Wage inequality and varieties of capitalism'. World Politics 52(3):350-83.

Samuelson, Paul. 1971. 'Ohlin was Right'. Swedish Journal of Economics 73(4):365-84.

Stolper, Wolfgang, and Samuelson Paul. 1941. 'Protection and real wages'. Review of Economic Studies 9(1):58-73.

Thewissen, Stefan. 2014. 'Is it the income distribution or redistribution that affects growth?'. SocioEconomic Review 12(3):545-71.

Thewissen, Stefan, Olaf van Vliet, and Chen Wang. 2017. Taking the Sector Seriously: Data, Developments and Drivers of Intrasectoral Earnings Inequality, Social Indicators Research, forthcoming (doi: 10.1007/s11205-017-1677-2).

Van Vliet, Olaf, and Koen Caminada. 2012. Unemployment replacement rates dataset among 34 welfare states 1971-2009: An update, extension, and modification of the Scruggs' welfare state entitlements data set, NEUJOBS Special Report No. 2, Leiden University, Leiden.

Visser, Jelle. 2013. ICTWSS: Database on institutional characteristics of trade unions, wage setting, state intervention and social pacts in 34 countries between 1960 and 2012 version 4, http://www.uvaaias.net/208, accessed 3 March 2014.

Wallerstein, Michael. 1999. 'Wage setting institutions and pay inequality in advanced industrial societies'. American Journal of Political Science 43(3):649-80.

Walter, Stefanie. 2010. 'Globalization and the welfare state: Testing the microfoundations of the compensation hypothesis'. International Studies Quarterly 54(2):403-26.

Williams, Laron K., and Guy D. Whitten. 2012. 'But wait, there's more! Maximizing substantive inferences from TSCS models'. Journal of Politics 74(3):685-93.

Wren, Anne. 2013. 'Introduction: The political economy of post-industrial societies'. In: Anne Wren ((ed.)), The political economy of the service transition, 1-70. Oxford: Oxford University Press. 